\title{
KARAKTERISTIK MARSHALL LAPISAN AUS ASPAL BETON MENGGUNAKAN AGREGAT TERSELIMUT LIMBAH PLASTIK LDPE (LOW DENSITY POLYETHYLENE)
}

\author{
Ni Luh Shinta Eka Setyarini', Anissa Noor Tajudin², Joseph Pratama ${ }^{3}$ \\ ${ }^{1}$ Jurusan Teknik Sipil, Universitas Tarumanagara Jakarta \\ Email:niluhs@ft.untar.ac.id \\ ${ }^{2}$ Jurusan Teknik Sipil, Universitas Tarumanagara Jakarta \\ Email:anissat@ft.untar.ac.id \\ ${ }^{3}$ Jurusan Teknik Sipil, Universitas Tarumanagara Jakarta \\ Email:joseppratama95@gmail.com
}

Masuk: 06-04-2018, revisi: 12-09-2019, diterima untuk diterbitkan: 12-09-2019

\begin{abstract}
ABSTRAK
Jalan merupakan infrastruktur penting untuk pergerakan manusia, barang dan meningkatkan perekonomian nasional, namun sebagian besar jalan berperkerasan lentur mengalami kerusakan akibat kualitas dari materialnya yaitu aspal dan agregat. Aspal adalah bahan yang tidak terbarukan sehingga akan habis akibat dari penggunaan secara terus menerus. Sehingga diperlukan bahan alternatif sebagai pengganti aspal untuk melapisi agregat yang berfungsi untuk mengurangi erosi. Salah satu bahan alternatif yang bisa digunakan untuk menutupi permukaan agregat adalah limbah plastik Low Density Polyethylene (LDPE). Limbah plastik LDPE yang digunakan sebanyak $1 \%$ - 6\% dari berat keseluruhan agregat di dalam campuran. Limbah plastik LDPE dibuat dalam bentuk potongan kecil plastik dengan ukuran benda uji dibuat berdiameter 4 " dan tinggi 2,7" dalam bentuk silinder. Pengujian Marshall dilakukan pada semua benda uji. Penambahan limbah plastik LDPE dapat meningkatkan stabilitas hingga $66,70 \%$ dan menurunkan kadar aspal hingga 2,5\% dibandingkan campuran aspal beton tanpa campuran limbah plastik.
\end{abstract}

Kata Kunci: aspal beton; limbah plastik LDPE; marshall; stabilitas dan flow

\section{ABSTRACT}

Roads are important infrastructure for the movement of people, goods and improving the national economy, but most flexible pavement roads suffer damage due to the quality of their material, namely asphalt and aggregate. Asphalt is a non-renewable material that will run out as a result of continuous use. So we need an alternative material as a substitute for asphalt to coat the aggregate which serves to reduce erosion. One alternative material that can be used to cover aggregate surfaces is Low Density Polyethylene (LDPE) plastic waste. The LDPE plastic waste used is 1\% - 6\% of the total weight of the aggregate in the mixture. LDPE plastic waste is made in the form of small pieces of plastic with the size of the test specimen made in diameter 4 "and height 2.7" in cylindrical form. Marshall testing is carried out on all test specimens. The addition of LDPE plastic waste can increase stability up to $66.70 \%$ and reduce asphalt content up to $2.5 \%$ compared to concrete asphalt mixture without plastic waste mixture.

Keywords: concrete asphalt; LDPE plastic waste; marshall; stability and flow

\section{PENDAHULUAN}

Pada tahun 2017 Kementrian Pekerjaan Umum dan Perumahan Rakyat menganggarkan dana perbaikan dan pemeliharaan jalan mencapai 18,7 triliun untuk 47.000 kilometer panjang jalan Nasional agar dapat menjadi jalan Nasional yang layak dan berkeselamatan. Untuk mencapai hal ini, penyediaan infrastruktur transportasi darat tidak dapat dilepaskan dari penyediaan bahan konstruksi jalan. Bahan konstruksi untuk perkerasan lentur adalah aspal dan agregat. Aspal yang 
dipergunakan untuk bahan perkerasan jalan berfungsi untuk melapisi agregat agar tidak terjadi erosi. Aspal merupakan bahan baku terbuat yang dari pelapukan fosil , tidak terbarukan dan bila penggunaannya tidak dibatasi dalam jangka panjang ketersediaannya akan habis. Oleh karena itu diperlukan suatu material alternatif pengganti aspal, bahan alternatif yang dipilih adalah limbah plastik Low Density Polyethylene (LDPE) yang diperoleh dari limbah kantong plastik. Penggunaan limbah plastik LDPE sangat menguntungkan secara ekonomis, mengingat bahan ini sangat mudah didapat dan sangat murah harganya, disamping juga memberikan pengaruh baik terhadap lingkungan dengan tereduksinya limbah plastik LDPE dalam jumlah yang besar.

Menurut Sukirman (2003), aspal merupakan bahan yang pada suhu ruang akan berbentuk padat sampai kepada agak padat, dan bersifat termoplastik. Jadi aspal akan meleleh pada suhu $50^{\circ} \mathrm{C}$ sesuai dengan tabel 2," Karakteristik Aspal" dan akan padat kembali jika suhunya diturunkan. Aspal dan agregat, adalah material campuran perkerasan lentur. Pengaruh cuaca, terutama curah hujan yang merendam lapisan konstruksi perkerasan lentur akan mempercepat kerusakan jalan dan pelapukan agregat. Oleh karena itu diperlukan suatu material yang dapat membantu melapisi bahan agregrat selain aspal agar dapat mengurangi pengaruh tersebut.

Menurut Razak dan Erdiansa (2016), bahan plastik dipilih sebagai bahan aditif karena jumlahnya yang banyak tersedia di alam sebagai limbah yang tidak mudah terurai serta kandungan senyawa yang ada pada aspal sangat memungkinkan diperkuat ketahanannya melalui reaksi dengan bahan sintesis maupun polimer. Selain mengoptimalkan karakteristik aspal, penggunaan plastik juga dapat mengurangi kerusakan lingkungan.

Vasudevan (2013), Penggunaan limbah plastik sebesar 10\% dalam campuran perkerasan, akan dapat mengurangi 3\% rongga dari campuran konvensional. Penggunaan limbah plastik LDPE sebagai pelapis agregat diharapkan dapat memberikan perbaikan kualitas campuran perkerasan terutama dari segi karakteristik campuran beton aspal.

Menurut Jonathan C. (2017), nilai stabilitas cenderung meningkat bila campuran aspal beton diselimuti limbah plastik LDPE dengan hasil nilai stabilitas meningkat sebanyak $63.75 \%$ pada pembuatan benda uji dengan kadar aspal mendekati optimum $6 \%$ dalam perendaman 30 menit.

Penelitian ini juga diharapkan dapat memberikan alternatif pemanfaatan limbah plastik LDPE yang ada dengan peningkatan jumlah limbah yang dipergunakan yaitu 1-6\% dari berat agregat keseluruhan dalam campuran, apabila dibandingkan dengan penelitian terdahulu yang hanya mengganti agregat halusnya saja. Sehingga dapat berkontribusi lebih besar untuk mengurangi pencemaran dan degradasi lingkungan akibat limbah plastik LDPE yang dipakai dalam jumlah yang lebih besar. Pemanfaatan lebih banyak limbah plastik LDPE sebagai bahan tambahan diharapkan dapat meningkatkan sifat-sifat fisik campuran beton aspal dan karakteristiknya.

\section{Tujuan}

Penelitian ini bertujuan untuk membandingkan nilai karakteristik Marshall dari campuran Agregat dan Aspal dengan penambahan limbah plastik LDPE pada Lapisan Aus gradasi halus dengan campuran konvensional, serta membantu memberi solusi baru untuk penanganan limbah plastik yang ada saat ini. 


\section{Rumusan Masalah}

Permasalahan dalam penelitian ini adalah bagaimana perbandingan antara uji nilai karakteristik Marshall antara campuran beton aspal konvensional dan campuran aspal beton dengan penambahan limbah plastik LDPE?

\section{Batasan Masalah}

Dalam penelitian ini, permasalahnya dibatasi hanya pada perbandingan nilai karakteristik marshall campuran Aspal Beton lapisan Aus dengan menggunakan limbah plastik LDPE sebagai pelapis agregat dengan campuran Aspal Beton konvensional. Penelitian ini dilakukan di laboratorium dengan uji marshall dan pengumpulan data berupa jurnal dan literatur sebagai acuan untuk dasar teori.

\section{METODOLOGI PENELITIAN}

Limbah plastik yang digunakan dalam penelitian ini berfungsi sebagai bahan tambahan untuk melapisi agregat dalam campuran Aspal Beton. Pengujian yang dilakukan dalam penelitian ini sesuai dengan pedoman Spesifikasi Umum Bina Marga Divisi 6 tahun 2010 revisi III sesuai dengan grafik 2 dan tabel 1.. Tahapan penelitian terdiri dari tahap persiapan, pembuatan benda uji dengan ukuran benda uji dibuat berdiameter 4 " dan tinggi 2,7" dalam bentuk silinder , pengujian benda uji dengan metoda Marshall, analisis dan pembahasan hasil pengujian serta kesimpulan. Pengujian yang dilaksanakan adalah pengujian Marshall dari benda uji tanpa penambahan limbah plastik LDPE dan dengan mempergunakan bahan tambahan limbah plastik LDPE. Hasil pengujian dari Marshall adalah berupa Karakteristik Marshall yaitu : Densitas, Stabilitas, VFWA, VITM, VMA dan Flow. Diharapkan hasil yang diperoleh dari benda uji dengan penambahan limbah plastik LDPE akan menghasilkan karakteristik yang lebih baik dari campuran Aspal Beton konvensional.

Lapisan Aspal Beton (Laston) adalah lapisan bergradasi menerus yang umumnya digunakan untuk jalan dengan beban lalu lintas berat. Laston dikenal pula dengan nama AC (Asphalt Concrete). Gradasi yang dipakai pada campuran penelitian ini adalah menggunakan persyaratan seperti gambar 1 di bawah ini, yaitu batas tengah:

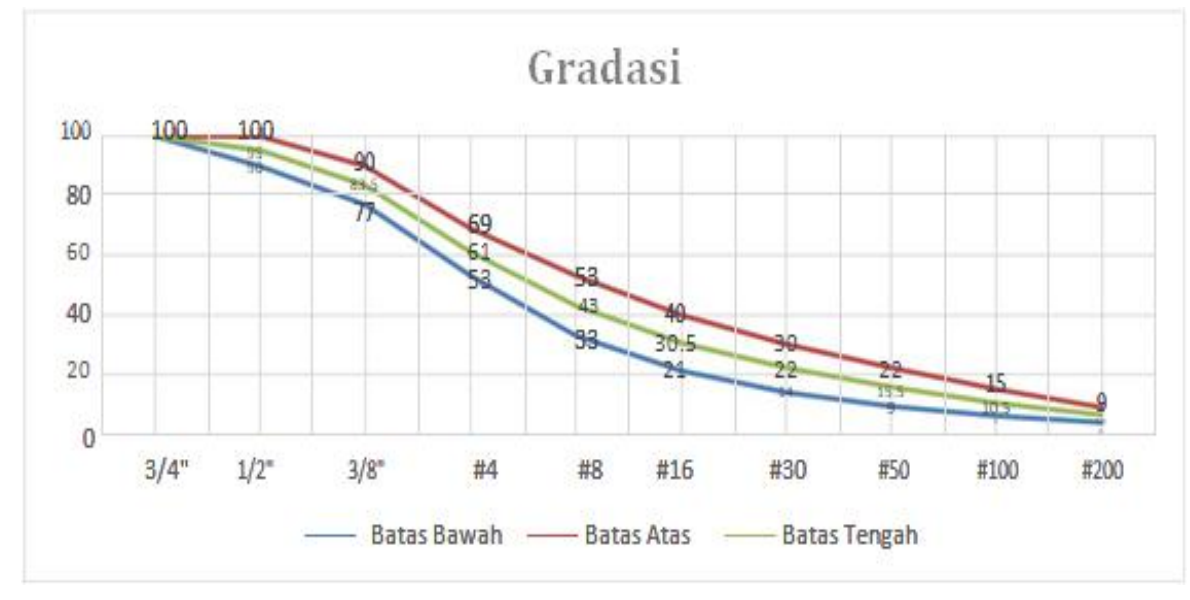

Gambar 2. Grafik Gradasi Agregat dalam Campuran 


\section{HASIL DAN PEMBAHASAN}

Hasil yang didapatkan dari pengujian properti Agregat yang dilakukan berupa pengujian berat jenis, kekuatan agregat yaitu Impact, Crushing dan Abrasi, serta bentuk agregat yaitu kepipihan dan kelonjongan.Untukpengujian properti Aspal yang dilaksanakan adalahberat jenis, daktilitas, penetrasi titik nyala dan titik leleh. Uji properties plastik yang dilaksanakan adalah berat jenis. Hasil pengujian dapat dilihat pada Tabel 3. sampai dengan Tabel 13. Yang meliputi hasil uji properti bahan agregat, aspal dan limbah plastik LDPE, dimana seluruh pengujian yang dilaksanakan menunjukkan bahwa bahan yang dipergunakan untuk benda uji memenuhi spesifikasi yang ditetapkan.

Tabel 1. Hasil pengujian karakteristik agregat

\begin{tabular}{ccccc}
\hline Agregat & Spesifikasi & Hasil & Satuan & Keterangan \\
\hline BJ. Agregat Kasar & Min 2.5 & 2.54 & $\mathrm{gr} / \mathrm{cm}^{3}$ & memenuhi \\
\hline BJ. Agregat Halus & Min 2.5 & 2.5 & $\mathrm{gr} / \mathrm{cm}^{3}$ & memenuhi \\
\hline BJ. Filler & Min 2.5 & 2.5 & $\mathrm{gr} / \mathrm{cm}^{3}$ & memenuhi \\
\hline Impact & $\leq 30 \%$ & 11 & $\%$ & memenuhi \\
\hline Crushing & $\leq 30 \%$ & 6 & $\%$ & memenuhi \\
\hline Kelekatan Aspal & $\geq 95 \%$ & 97 & $\%$ & memenuhi \\
\hline Abrasi Agregat dengan mesin LA & Max. $40 \%$ & 22.9 & $\%$ & memenuhi \\
\hline Kepipihan dan Kelonjongan & Max. $10 \%$ & $8.2 ; 9.4$ & $\%$ & memenuhi \\
\hline
\end{tabular}

Tabel 2. Hasil pengujian karakteristik aspal dan plastik

\begin{tabular}{cccc}
\hline Aspal & Spesifikasi & Hasil & Keterangan \\
\hline Penetrasi pada $25^{\circ} \mathrm{C}(\mathrm{mm})$ & $60 / 70$ & $63.2 / 70$ & memenuhi \\
\hline Daktilitas pada $25^{\circ} \mathrm{C}(\mathrm{cm})$ & $\geq 100 \mathrm{~cm}$ & $112 \mathrm{~cm}$ & memenuhi \\
\hline BJ. Aspal $\left(\mathrm{gr} / \mathrm{cm}^{3}\right)$ & $\geq 1$ & 1.025 & memenuhi \\
\hline Titik Lembek $\left({ }^{0} \mathrm{C}\right)$ & $\geq 48^{0} \mathrm{C}$ & $50{ }^{\circ} \mathrm{C}$ & memenuhi \\
\hline Titik Nyala dan Titik Bakar $\left({ }^{0} \mathrm{C}\right)$ & $\geq 232^{\circ} \mathrm{C}$ & $290{ }^{\circ} \mathrm{C} ; 309{ }^{0} \mathrm{C}$ & memenuhi \\
\hline Berat Jenis Plastik & $\geq 0.91 \mathrm{gr} / \mathrm{cm}^{3}$ & 1.14 & memenuhi \\
\hline
\end{tabular}

\section{Pengujian Marshall Dengan Perendaman Standar (30 Menit)}

Hasil uji Marshall dari campuran aspal beton kontrol/ konvensional (plastik 0\%) dan campuran aspal beton dengan tambahan limbah plastik LDPE dengan kadar kadar plastik 1\%,2\%,3\%,4\%, $5 \%$, dan 6\% dari berat agregat keseluruhan ,dengan kadar aspal 4\% hingga 7\% dapat dilihat pada Tabel 3 hingga Tabel 9 di sebagai berikut: dimana sebagian besar dari hasil pengujian memenuhi persyaratan spesifikasi.

Tabel 3. Hasil pengujian marshall (plastik 0\%)

\begin{tabular}{|c|c|c|c|c|c|c|}
\hline \multirow{3}{*}{ Kriteria } & \multirow{3}{*}{ Spesifikasi } & \multicolumn{4}{|c|}{$\%$ Aspal } & \multirow{2}{*}{ Keterangan } \\
\hline & & 4 & 5 & 6 & 7 & \\
\hline & & \multicolumn{4}{|c|}{ Hasil } & \\
\hline Densitas & - & 2,16 & 2,19 & 2,23 & 2,21 & memenuhi \\
\hline VFWA & $>65 \%$ & 44,83 & 56,24 & 72,27 & 76,04 & ada memenuhi \\
\hline VITM & $3-5 \%$ & 10,00 & 7,91 & 5,00 & 4,45 & ada memenuhi \\
\hline$\overline{\text { VMA }}$ & $>15 \%$ & 18,12 & 18,07 & 18,04 & 18,59 & memenuhi \\
\hline Stabilitas & $>800 \mathrm{~kg}$ & 1293,70 & 1335,98 & 1527,09 & 1102,80 & memenuhi \\
\hline Flow & $>2 \mathrm{~mm}$ & 6,08 & 6,51 & 7,87 & 8,31 & memenuhi \\
\hline
\end{tabular}


Untuk campuran dengan penambahan limbah plastik LDPE hasilnya dapat dilihat pada Tabel 4, $5,6,7,8$, dan 9 , pada kadar plastik $1 \%$ sampai dengan kadar plastik $6 \%$, dimana nilai density, VMA, stabilitas, dan flow sudah memenuhi spesifikasi, sedangkan nilai VFWA dan VITM tidak memenuhi.

Tabel 4. Hasil pengujian marshall (plastik 1\%)

\begin{tabular}{|c|c|c|c|c|c|c|}
\hline \multirow{3}{*}{ Kriteria } & \multirow{3}{*}{ Spesifikasi } & \multicolumn{4}{|c|}{$\%$ Aspal } & \multirow{3}{*}{ Keterangan } \\
\hline & & 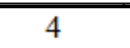 & 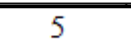 & 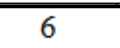 & $\overline{77}$ & \\
\hline & & \multicolumn{4}{|c|}{ Hasil } & \\
\hline Densitas & - & 2,11 & 2,14 & 2,15 & 2,13 & memenuhi \\
\hline VFWA & $>65 \%$ & 38,91 & 50,28 & 58,26 & 62,70 & tidak memenuhi \\
\hline VITM & $3-5 \%$ & 12,48 & 9,86 & 8,50 & 8,10 & tidak memenuhi \\
\hline VMA & $>15 \%$ & 20,38 & 19,81 & 20,35 & 21,69 & memenuhi \\
\hline Stabilitas & $>800 \mathrm{~kg}$ & 1312,25 & 1475,31 & 1609,31 & 1328,03 & memenuhi \\
\hline Flow & $>2 \mathrm{~mm}$ & 6,42 & 7,62 & 9,73 & 10,41 & memenuhi \\
\hline
\end{tabular}

Tabel 5. Hasil pengujian Marshall kontrol (plastik 2\%)

\begin{tabular}{|c|c|c|c|c|c|c|}
\hline \multirow[t]{2}{*}{ Kriteria } & \multirow[t]{2}{*}{ Spesifikasi } & \multicolumn{4}{|c|}{$\%$ Aspal } & \multirow[t]{3}{*}{ Keterangan } \\
\hline & & 4 & 5 & 6 & 7 & \\
\hline & \multicolumn{5}{|c|}{ Hasil } & \\
\hline Densitas & - & 2,10 & 2,16 & 2,15 & 2,12 & memenuhi \\
\hline VFWA & $>65 \%$ & 38,32 & 53,31 & 58,30 & 61,64 & tidak memenuhi \\
\hline VITM & $3-5 \%$ & 12,69 & 8,86 & 8,49 & 8,43 & tidak memenuhi \\
\hline VMA & $>15 \%$ & 20,57 & 18,91 & 20,35 & 21,98 & memenuhi \\
\hline Stabilitas & $>800 \mathrm{~kg}$ & 1627,57 & 1723,56 & 1795,35 & 1362,95 & memenuhi \\
\hline Flow & $>2 \mathrm{~mm}$ & 7,30 & 7,62 & 9.52 & 9,92 & memenuhi \\
\hline
\end{tabular}

Tabel 6. Hasil pengujian marshall kontrol (plastik 3\%)

\begin{tabular}{|c|c|c|c|c|c|c|}
\hline \multirow{3}{*}{ Kriteria } & \multirow{3}{*}{ Spesifikasi } & \multicolumn{4}{|c|}{ \% Aspal } & \multirow{3}{*}{ Keterangan } \\
\hline & & 4 & 5 & 6 & 7 & \\
\hline & & \multicolumn{4}{|c|}{ Hasil } & \\
\hline Densitas & - & 2,06 & 2,11 & 2,11 & 2,12 & memenuhi \\
\hline VFWA & $>65 \%$ & 35,87 & 46,72 & 54,73 & 61,44 & tidak memenuhi \\
\hline VITM & $3-5 \%$ & 14,25 & 11,21 & 9,89 & 8,53 & tidak memenuhi \\
\hline VMA & $>15 \%$ & 21,99 & 21,01 & 21,56 & 22,06 & memenuhi \\
\hline Stabilitas & $>800 \mathrm{~kg}$ & 1586,18 & 1622,35 & 1859,38 & 1158,23 & memenuhi \\
\hline Flow & $>2 \mathrm{~mm}$ & 9,73 & 11,51 & 11,94 & 12,69 & memenuhi \\
\hline
\end{tabular}


Tabel 7. Hasil pengujian marshall kontrol (plastik 4\%)

\begin{tabular}{|c|c|c|c|c|c|c|}
\hline \multirow{3}{*}{ Kriteria } & \multirow{3}{*}{ Spesifikasi } & \multicolumn{4}{|c|}{$\%$ Aspal } & \multirow{3}{*}{ Keterangan } \\
\hline & & 4 & 5 & 6 & 7 & \\
\hline & & \multicolumn{4}{|c|}{ Hasil } & \\
\hline Densitas & - & 2,15 & 2,16 & 2,14 & 2,12 & memenuhi \\
\hline VFWA & $>65 \%$ & 44,23 & 52,52 & 56,74 & 61,61 & tidak memenuhi \\
\hline$\overline{\text { VITM }}$ & $3-5 \%$ & 10,78 & 9,07 & 8,99 & 8,44 & tidak memenuhi \\
\hline VMA & $>15 \%$ & 19,35 & 19,10 & 20,78 & 21,98 & memenuhi \\
\hline Stabilitas & $>800 \mathrm{~kg}$ & 2060,85 & 1388,83 & 1155,73 & 875,21 & memenuhi \\
\hline Flow & $>2 \mathrm{~mm}$ & 6,09 & 8,90 & 11,42 & 12,18 & memenuhi \\
\hline
\end{tabular}

Tabel 8. Hasil Pengujian Marshall Kontrol (Plastik 5\%)

\begin{tabular}{|c|c|c|c|c|c|c|}
\hline \multirow{3}{*}{ Kriteria } & \multirow{3}{*}{ Spesifikasi } & \multicolumn{4}{|c|}{$\%$ Aspal } & \multirow{3}{*}{ Keterangan } \\
\hline & & 4 & 5 & 6 & 7 & \\
\hline & & \multicolumn{4}{|c|}{ Hasil } & \\
\hline Densitas & - & 2,08 & 2,10 & 2,12 & 2,13 & memenuhi \\
\hline VFWA & $>65 \%$ & 36,23 & 45,56 & 54,40 & 62,38 & tidak memenuhi \\
\hline VITM & $3-5 \%$ & 13,71 & 11,67 & 9,80 & 8,19 & tidak memenuhi \\
\hline VMA & $>15 \%$ & 21,50 & 21,42 & 21,48 & 21,77 & memenuhi \\
\hline Stabilitas & $>800 \mathrm{~kg}$ & 2291,28 & 1480,24 & 888,83 & 784,31 & memenuhi \\
\hline Flow & $>2 \mathrm{~mm}$ & 7,79 & 9,92 & 12,19 & 12,94 & memenuhi \\
\hline
\end{tabular}

Tabel 9. Hasil Pengujian Marshall Kontrol (Plastik 6\%)

\begin{tabular}{|c|c|c|c|c|c|c|}
\hline \multirow[t]{3}{*}{ Kriteria } & \multirow[t]{3}{*}{ Spesifikasi } & \multicolumn{4}{|c|}{$\%$ Aspal } & \multirow[t]{3}{*}{ Keterangan } \\
\hline & & 4 & 5 & 6 & 7 & \\
\hline & & \multicolumn{4}{|c|}{ Hasil } & \\
\hline Densitas & $>2$ & 2,03 & 2,06 & 2,12 & 2,12 & ada memenuhi \\
\hline VFWA & $>65 \%$ & 32,92 & 41,62 & 54,53 & 61,54 & tidak memenuhi \\
\hline VITM & $3-5 \%$ & 15,53 & 13,40 & 9,75 & 8,46 & tidak memenuhi \\
\hline VMA & $>15 \%$ & 23,16 & 22,95 & 21,44 & 22,00 & memenuhi \\
\hline Stabilitas & $>800 \mathrm{~kg}$ & 2498,39 & 1046,78 & 809,10 & 652,86 & memenuhi \\
\hline Flow & $>2 \mathrm{~mm}$ & 9.65 & 9.93 & 10.15 & 11,17 & memenuhi \\
\hline
\end{tabular}




\section{Densitas}

Densitas merupakan perbandingan antara berat terhadap volume campuran yang menunjukan tingkat kepadatan dari campuran yang telah dilakukan pemadatan. Semakin tinggi tingkat kepadatan dari suatu perkerasan maka kekuatan dari perkerasan untuk menahan beban juga semakin baik.

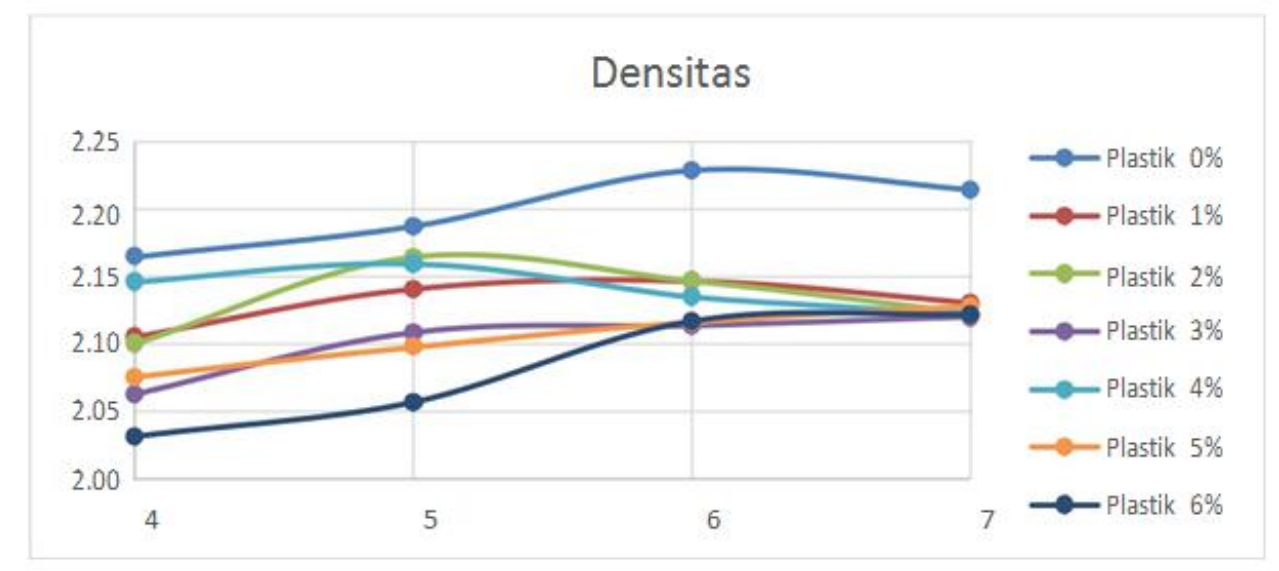

Gambar 3. Grafik kadar aspal terhadap Densitas

\section{Void Filled With Asphalt (VFWA)}

Void Filled With Asphalt (VFWA) adalah persentase rongga yang terdapat diantara agregat yang terisi oleh aspal, dalam hal ini tidak termasuk pada aspal yang diserap oleh rongga agregat. Hubungan kadar aspal pada pengujian campuran aspal beton terhadap nilai VFWA dapat dilihat pada Gambar 4 semakin tinggi kadar aspal semakin tinggi juga nilai VFWA.

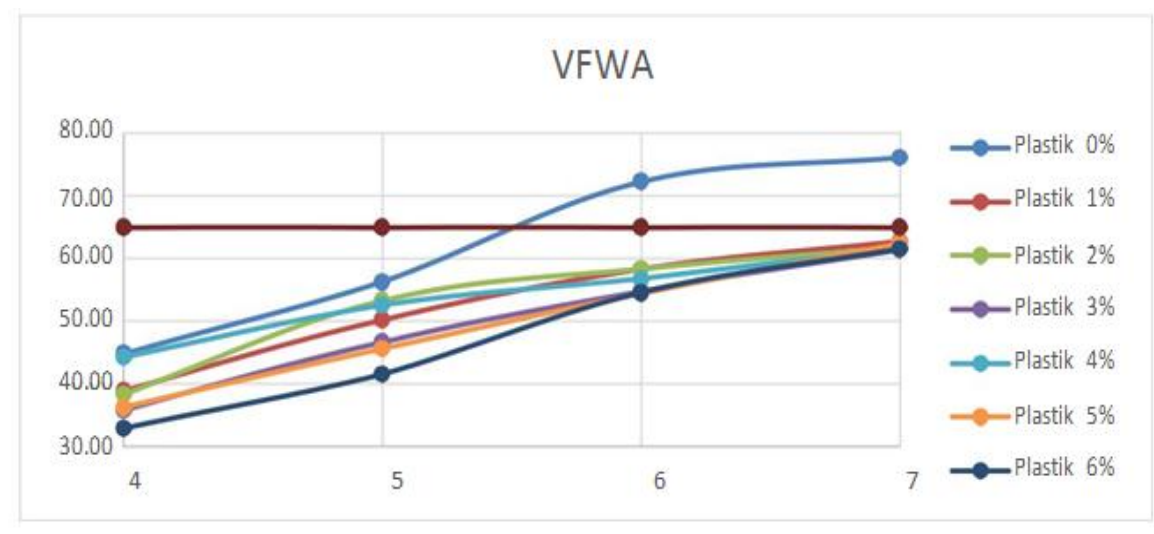

Gambar 4. Grafik kadar aspal terhadap VFWA

\section{Void In The Mix (VITM)}

Dalam campuran perkerasan beraspal terdapat ruang udara diantara partikel agregat yang terselimuti oleh aspal. Hubungan kadar aspal pada pengujian terhadap nilai VITM dapat dilihat pada Gambar 5. Nilai rongga pada campuran dipengaruhi oleh kadar aspal pada campuran aspal beton. Penambahan limbah plastik LDPE menyebabkan rongga pada campuran menjadi 
meningkat karena limbah plastik LDPE menggumpal dan membuat jarak antar agregat menjadi semakin besar, hal inilah menyebabkan nilai VITM menjadi meningkat.

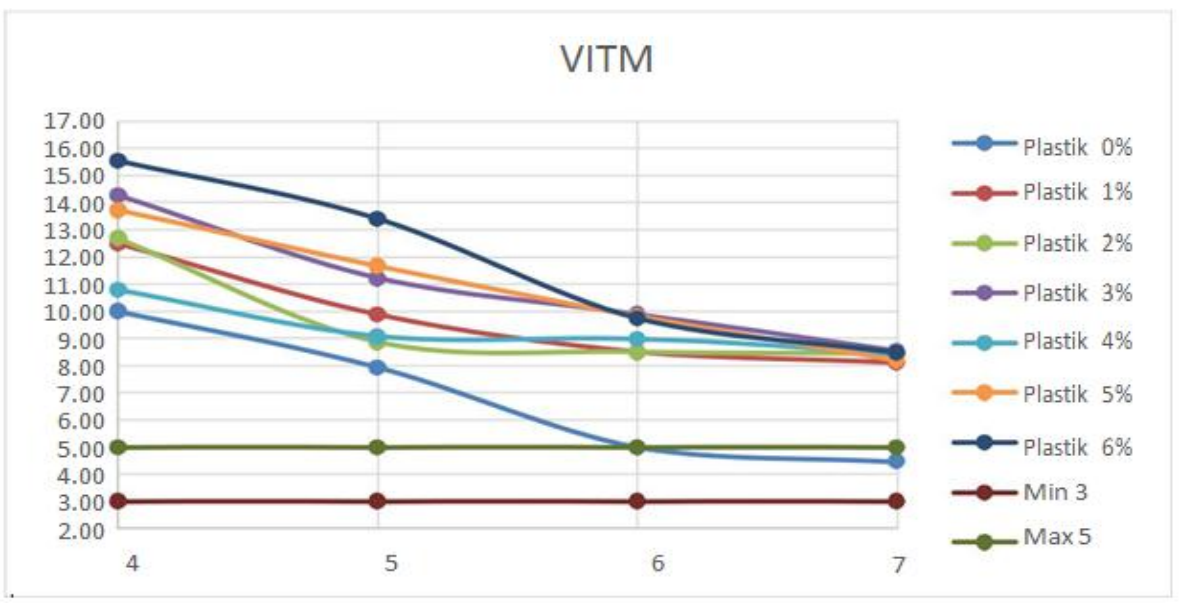

Gambar 5. Grafik kadar aspal terhadap VITM

\section{Stabilitas}

Pengujian stabilitas untuk mengukur ketahanan campuran terhadap besarnya pembebanan, semakin besar nilai stabilitas maka ketahanan campuran terhadap pembebanan akan semakin tinggi. Pengukuran dilakukan dengan menempatkan benda uji pada alat Marshall. Beban saat keruntuhan dibaca pada dial proving ring. Penambahan kadar aspal pada campuran akan meningkatkan nilai stabilitas. Hal ini dikarenakan fungsi dari aspal sebagai perekat untuk agregat dapat bekerja dengan lebih baik. Penggunaan limbah plastik LDPE pada campuran Aspal Beton meningkatkan nilai stabilitas. Hal ini disebabkan oleh sifat plastis dari limbah plastik LDPE saat pemadatan, limbah plastik LDPE akan berfungsi sebagai perekat antar agregat. Grafik pada gambar 6 menunjukkan nilai stabilitas tertinggi diperoleh pada benda uju dengan kadar plastik 6\% dan kadar kadar adpal 4\%. Sedangkan stabilitas tertinggi pada campuran konvensional terjadi pada kadar aspal $0 \%$ yaitu sebesar $1560 \mathrm{~kg}$. Dengan penambahan limbah plastik LDPE menunjukkan peningkatan nilai stabilitas secara simultan.

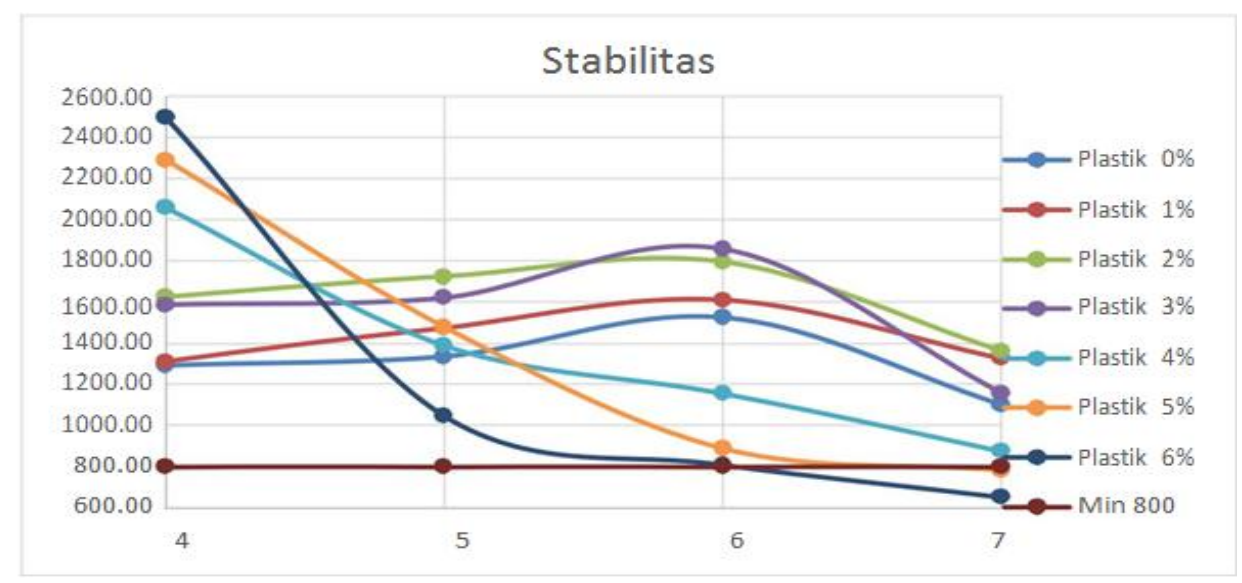

Gambar 6. Grafik kadar aspal terhadap stabilitas 
Dari Gambar 6 terlihat, bahwa dengan penambahan kadar plastik LDPE maka nilai stabilitas cenderung meningkat apabila dibandingkan dengan nilai Stabilitas pada campuran dengan kadar plastik $0 \%$. Pada kadar plastik 6\% dengan kadar aspal $4 \%$ memiliki nilai stabilitas yang tertinggi yaitu $2498,39 \mathrm{~kg}$, tetapi dengan semakin meningkatnya kadar aspal pada campuran mengakibatkan stabilitas menjadi semakin menurun.

\section{Nilai VMA}

Void in Mineral Aggregate (VMA) adalah ruang rongga diantara butiran agregat pada suatuperkerasan, termasuk rongga udara dan volume aspal efektif (tidak termasuk volume aspal yang diserap oleh agregat). Hubungan kadar aspal pada pengujian terhadap nilai VMA dapat dilihat pada Gambar 7. Dengan adanya limbah plastik LDPE menyebabkan rongga campuran menjadi bertambah dan membuat nilai VMA menjadi besar.

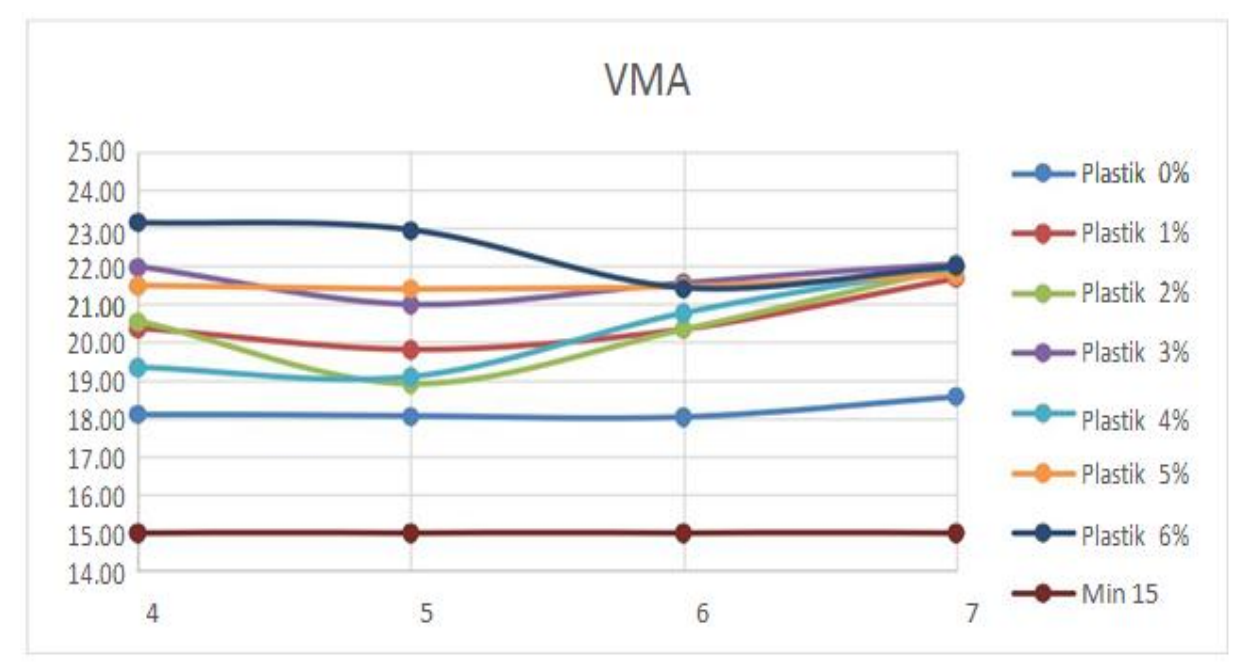

Gambar 7.Grafik kadar aspal terhadap VMA

\section{Nilai Flow Marshall}

Nilai flow pada flowmeter, yang dibaca pada nilai dial pengukur saat keruntuhan. Nilai flow digunakan untuk mengukur deformasi yang terjadi akibat pembebanan. Hubungan kadar aspal pada pengujian terhadap nilai flow dapat dilihat pada Gambar 8. Flow tertinggi terjadi pada kadar aspal 7\% dengan kadar plastik 4\%, sedangkan nilai Flow terendah pada kadar plastik 6\% dan kadar aspal 4\%, dimana nilai terendah ini masih memenuhi persyaratan spesifikasi. Penambahan kadar aspal tidak selalu memberikan peningkatan nilai flow, pada kondisi campuran optimum akan diperoleh nilai stabilitas tertinggi dan nilai flow yang rendah. 


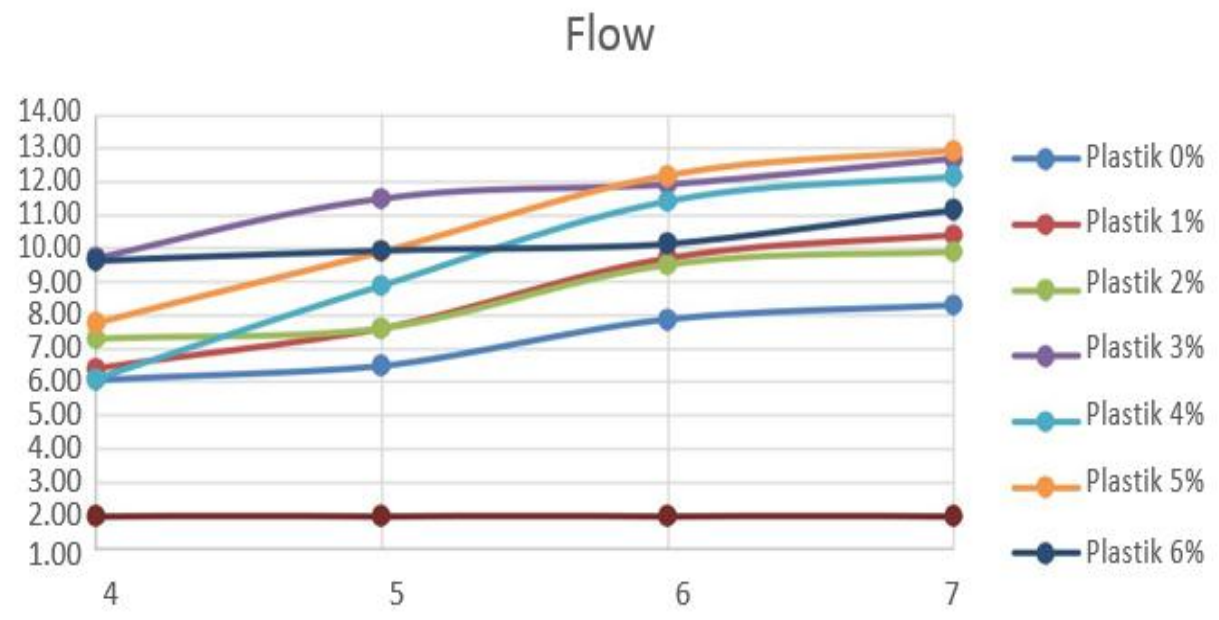

Gambar 8. Grafik kadar aspal terhadap Flow

\section{Pembahasan Kelayakan Penggunaan Limbah Plastik LDPE Dalam Campuran}

Analisa kelayakan penggunaan limbah plastik LDPE pada campuran dapat ditinjau dari beberapa aspek antara lain dari segi teknis, ekonomi, dan lingkungan.

1. Segi teknis, melihat data yang didapat dari hasil penelitian, campuran aspal beton dengan tambahan limbah plastik LDPE memenuhi spek Bina Marga bila dilihat dari karakteristik marshall. Karenanya, campuran dengan limbah plastik LDPE sebagai pelapis agregat layak untuk alternatif .

2. Segi ekonomi, biaya untuk pembuatan campuran akan berkurang akibat penambahan LDPE. Hal ini diakibatkan oleh berkurangnya aspal yang dipergunakan. Apabila konvensional memerlukan aspal 6,5\% /78gr dari total agregat $=1200$ gr sedangkan pada campuran dengan LDPE hanya memerlukan aspal 4\% / 48gr. LDPE telah berhasil menggantikan aspal sebanyak 2,5\% . Bila dihitung dengan harga aspal Rp. 2.750 .000 per barrel (100kg) dan harga plastik Rp. 500 per kg, maka: Harga aspal campuran konvensional: $(78 / 1000)$ x Rp. $27.500=\mathrm{Rp}$. 2145, harga aspal campuran modifikasi: $((48 / 1000) \times$ Rp. 27.500) $)+((72 / 1000) \times$ Rp. 500) $)=$ Rp. 1356. Penghematan: Rp. 2145- Rp. $1356=$ Rp. 789 atau sebesar 36,78\% dari biaya.

3. Segi lingkungan, memberikan alternatif pemanfaatan limbah plastik LDPE yang ada dengan peningkatan jumlah limbah yang dipergunakan yaitu 1-6\% dari berat agregat keseluruhan dalam campuran, apabila dibandingkan dengan penelitian terdahulu yang hanya mengganti agregat halusnya saja. Sehingga dapat berkontribusi lebih besar untuk mengurangi pencemaran dan degradasi lingkungan akibat limbah plastik LDPE yang dipakai dalam jumlah yang lebih besar.

\section{Penentuan Kadar Aspal Optimum Dengan Metode Narrow Range}

Gambar 9 Menunjukkan wilayah karakteristik dari kadar plastik LDPE 6\% dengan kadar Aspal 4\%,5\%,6\% dan 7\% ,yang memenuhi spesifikasi Bina Marga sehungga Kadar Aspal Optimum dapat ditentukan dengan mempergunakan metode Narrow Range. Dari kondisi gambar 7 diperoleh Kadar Aspal Mendekati optimum adalah 4\% dengan kadar plastik 6\%. 


\section{Narrow Range Plastik $6 \%$}

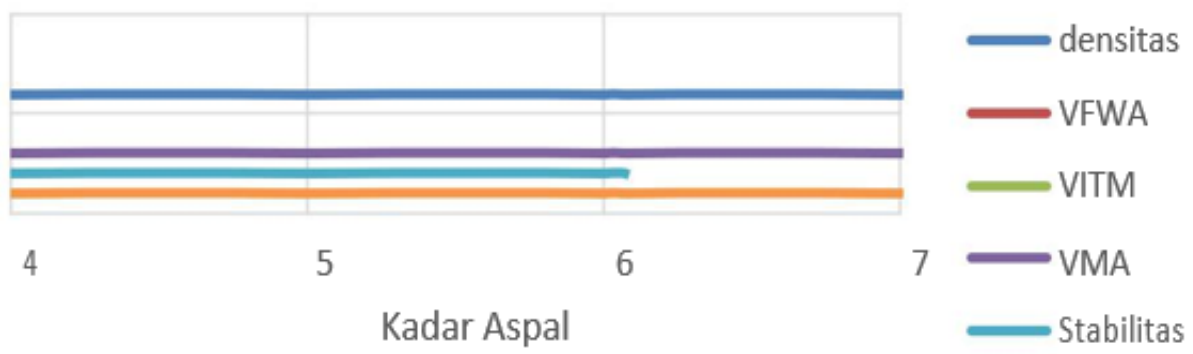

Gambar 9. Grafik Narror Range Kadar Plastik 6\% KAMO

\section{KESIMPULAN}

Berdasarkan penelitian yang telah dilakukan dengan menggunakan limbah plastik LowDensity Polyethylene (LDPE) sebagai pelapis agregat campuran Asphalt Concrete - Wearing Course (AC-WC), kesimpulan yang diperoleh adalah sebagai berikut:

1. Campuran aspal beton dengan kadar plastik $6 \%$ dan kadar aspal $4 \%$ memiliki nilai stabilitas tertinggi yaitu 2498,39 kg, membuktikan bahwa semakin banyak kadar plastik yang digunakan dalam campuran aspal beton akan dapat meningkatkan nilai stabilitas, sampai batas tertentu.

2. Dari hasil penelitian yang didapatkan, dapat disimpulkan bahwa terjadi penghematan sekitar 2,5\% aspal dengan penggunaan kadar plastik 6\% dalam campuran.

3. Nilai flow meningkat seiring dengan meningkatnya kadar plastik pada campuran aspal beton. Akan tetapi, nilai flow pada benda uji konvensional dengan KAO sebesar $6,5 \%$, nilai flow pada benda uji modifikasi kadar aspal mendekati optimum sebesar $4 \%$ dan plastik sebesar $6 \%$ tidaklah berbeda.

4. Dari segi ekonomi, biaya untuk membuat campuran akan berkurang akibat penambahan limbah plastik LDPE. Hal ini dapat dilihat dari berkurangnya aspal yang digunakan, dimana pada campuran konvensional memerlukan aspal 6,5\% atau 78gr terhitung dari total agregat 1200 gr. Sedangkan pada campuran aspal beton dengan LDPE hanya memerlukan aspal 4\% atau 48gr. Limbah plastik LDPE telah berhasil menggantikan aspal yang diperlukan 2,5\%. Bila dihitung dengan harga aspal sebesar Rp. 2.750.000 per barrel $(100 \mathrm{~kg})$ dan harga plastik sebesar Rp. 500 per kg, maka: harga aspal campuran 0\%: $(78 / 1000)$ x Rp. $27.500=$ Rp. 2145 harga aspal campuran modifikasi: $((48 / 1000) \times$ Rp. 27.500) + ((72/1000) x Rp. 500) = Rp. 1356. Maka penghematan: Rp. $2145-$ Rp. $1356=$ Rp. 789 sebesar

5. Dari segi lingkungan, memberikan alternatif pemanfaatan limbah plastik LDPE yang ada dengan peningkatan jumlah limbah yang dipergunakan yaitu 1-6\% dari berat agregat keseluruhan dalam campuran. sehingga dapat berkontribusi lebih besar terhadap degradasi lingkungan dengan berkurangnya limbah LDPE dalam jumlah yang besar di Alam. Hal ini tentu menjadi suatu solusi yang sangat baik untuk penanganan limbah plastik LDPE mengingat limbah plastik LDPE membutuhkan waktu yang cukup lama untuk terurai. 
6. Campuran AC-WC dengan limbah plastik LDPE sebagai pelapis, memang layak untuk diterapkan karena ditinjau dari aspek, yaitu teknik, ekonomi, dan lingkungan. Secara teknis penggunaan limbah plastik memenuhi syarat spesifikasi, secara ekonomi akan mengurangi biaya pemerintah dalam hal pembuangan limbah plastik, dan secara lingkungan menjadi solusi penanganan limbah plastik yang sulit terurai.

\section{SARAN}

1. Perlu dilakukan penelitian lebih lanjut pada jenis campuran yang sama atau berbeda dengan menggunakan ukuran plastik yang berbeda dengan kadar plastik yang lebih tinggi dari penelitian ini, mengingat kadar plastik tertinggi yang digunakan dalam penelitian ini masih memenuhi syarat spesifikasi.

2. Perlu dilakukan penelitian lebih lanjut mengenai penggunaan berbagai jenis limbah plastik sebagai alternatif pada berbagai macam campuran aspal. Dengan dilakukan hal tersebut, maka dapat dihasilkan campuran aspal yang terbaik untuk digunakan pada perkerasan jalan.

\section{DAFTAR PUSTAKA}

AASTHO. (1978). Standard Specifications For Transportation Materials And Mehods Of Sampling And Testing, Part 1 (Mehods Of Sampling And Testing).

Ashpalt Institute. (2001). Superpave Level 1 Mix Design. Superpave Series No. 2 (SP-2). Asphalt Institute, Kentucky.

Departemen Pekerjaan Umum. (1990). SNI M-58-1990. Metode Pengujian Aspal dengan Alat Marshall.

Direktorat Jenderal Bina Marga. (2010). Spesifikasi Umum Perkerasan Aspal Revisi 3. Kementerian Pekerjaan Umum, Jakarta.

Indian Road Congress. (2013). "Guidelines for The Use of Waste Plastic in Hot Bituminous Mixes (Dry Process) in Wearing Courses". Indian Road Congress, New Delhi.

Jonathan, C. (2017). "Karakteristik aspal beton menggunakan agregat terselimut limbah plastik Low Density Polyethylene (LDPE)". Universitas Tarumanagara, Jakarta.

Kementrian Pekerjaan Umum. (2014). Informasi Statistik Infrastruktur Pekerjaan Umum. Kementrian Pekerjaan Umum dan Rakyat, Jakarta.

Ojha, D. And Kumar, D. (2014). "A Proposed Design of Flexible Pavement using Waste Plastic". International Journal of Engineering and Management Research.

Rajasekaran, S., Vasudevan, R., Paulraj, S. (2013). "Reuse of Waste Plastics Coated AggregatesBitumen Mix Composite For Road Application- Green Method". American Journal of Engineering Research.

Razak, B. A., dan Erdiansa, A. (2016)." Karakteristik campuran AC-AC dengan penambahan limbah plastik low density polyethylene (LPDE)". Journal INTEK, 3(1), 8-14.

Sukirman, Silvia. (2003). Beton Aspal Campuran Panas. Granit, Bandung. 
Unde, S. R. And Potnis, S.C. (2015). Effective Utilization of Plastic Waste in Flexible Pavement and Analysis by Experimnets. Intenational Journal of Engineering Sciences \& Research Technology.

Vasudevan. (2013). Utilization of Waste Plastics in Rural Roads. College of Engineering, Madurai, India. 
KARAKTERISTIK MARSHALL LAPISAN AUS ASPAL BETON

MENGGUNAKAN AGREGAT TERSELIMUT LIMBAH PLASTIK LDPE (LOW DENSITY POLYETHYLENE) 